\title{
Pemeliharaan Itik Sistem Gembala Sebagai Upaya Peternak Itik Petelur Dalam Memanfaatkan Sumber Daya Alam Di Pesisir Danau Tondano Kabupaten Minahasa
}

\author{
Stevy P. Pangemanana*, E. Endoha*, J.O. Rawisa*, Z. Warouwa*, \\ aJurusan Sosial Ekonomi, Fakultas Peternakan, Universitas Sam Ratulangi
}

KATA KUNCI

Itik

Pakan

Gembala

\begin{abstract}
A B S T R A K
Ternak itik sudah lama dikembangkan di kabupaten Minahasa khususnya didaerah pinggiran danau Tondano yang memiliki luas 4.620 ha dan daerah persawahan kabupaten Minahasa yang cukup luas yaitu 13.002 ha. Daerah ini memiliki potensi sumber daya alam yang sesuai dengan perkembangan ternak itik sebagai sumber pakan alam. Penelitian ini bertujuan untuk mengetahui manfaat ekonomi dan manfaat lainnya dari system gembala yang dilakukan peternak. Penelitian menggunakan metode survery dan hasil dianalisis secara deskriptif tentang jumlah curahan tenaga kerja system gembala (JKSP) yang selanjutnya dikonversi sebagai biaya pakan alam ternak itik. Hasil penelitian menunjukan bahwa $64 \%$ peternak itik sistim gembala melakukan pindah lokasi daerah gembala kurang dari kurang dari 4 kali dalam setahun dan 36\% melakukan lebih dari 4 kali dalam setahun. Sistim gembala memberikan nilai ekonomi sebesar Rp.28.000 per hari utuk nilai pakan yang didapat di alam.

A B S T R A C T

Duck farming has long been developed in the minahasa distric, especially in the outskirt of tondano lake that has an area of 4.620 ha and paddy fields with an area of 13.002 ha. This area has potential natural resources for ducks as a natural feed resources. This research aims to determine the economic benefit dan other benefit of the duck rerar system. Research using survey methods and result are analyzed descriptively about the allocation labour (JKSP) of the duck rerar system which is further converted as the cost of feed ducks. The result showed that $64 \%$ of the farmers shepherd system did relocated less than 4 times a year and 36\% did more than four times a year. Duck rerar system provides economic value or Rp. 28.000 per day of the feed gained in nature
\end{abstract}

K E Y W OR D S

Duck

Feed

Scavenging

TERSEDIA ONLINE

\section{Oktober 2019}

\section{Pendahuluan}

Itik (Anas sp) merupakan salah satu jenis unggas yang diusahakan untuk menghasilkan telur dan daging. Di Indonesia itik mempunyai keberagaman jenis sesuai nama daerah perkembangannya dikenal dan memiliki sifat unggul diantaranya itik Tegal, itik Magelang, itik Mojosari, itik Jogjakarta, itik Bali, dan itik Alabio. Itik introduksi asing juga masuk dalam ruang usaha itik di Indonesia diantaranya itik Peking dan itik Buff. Perkembangan teknologi breeding (Balai Penelitian Ternak) di Indonesia telah dikembangkan beberapa jenis itik unggul sesuai dengan tujuan pemeliharaan seperti itik Serati sebagai itik pedaging, Itik Mojosari-Alabio (MA) sebagai itik petelur-pedaging dan lain sebagainya.

Ternak itik berpotensi sangat bagus di propinsi Sulawesi Utara. Produk itik berupa telur dan daging bermanfaat untuk memenuhi kebutuhan pangan dan gizi masyarakat Sulut. Telur itik memiliki kandungan protein yang tinggi dan harganya cukup terjangkau untuk masyarakat kalangan bawah.

*Stevy P. Pangemanan Corresponding author: Jurusan Sosial Ekonomi FakultasPeternakan . Universitas Sam Ratulangi Manado , Alamat Kampus Unsrat Bahu.;

Email address: stevypangemanan@unsrat.ac.id

Published by FMIPA UNSRAT (2019) 
Selain itu, telur itik sangat dibutuhkan untuk industri-industri pangan seperti pabrik kue, mie instant dan lain sebagainya. Peternakan itik di Propinsi Sulawesi Utara berkembang cukup banyak di daerah Kabupaten Minahasa (BPS Sulut, 2018) yang memiliki potensi sumber daya alam yang sesuai dengan perkembangan ternak tersebut. Ternak itik sudah lama dikembangkan khususnya didaerah danau Tondano yang memiliki luas 4.620 ha dan daerah persawahan kabupaten Minahasa yang cukup luas yaitu 13.002 ha.

Menurut Pangemanan (2018) menyatakan bahwa beternak itik di kabupaten Minahasa telah dilakukan secara turun temurun dan merupakan usaha mereka disamping bekerja sebagai petani dan usaha non pertanian. Itik dipelihara untuk tujuan produksi telur dan setelah produksinya berkurang diafkir untuk dijual dagingnya. Peternak itik didaerah ini umumnya adalah peternak itik petelur skala kecil yang mempunyai kebiasaan menggembalakan ternak dengan memanfaatkan potensi sumberdaya alam daerah gembalaannya sebagai pakan ternak yaitu sisa butiran padi, keong, serangga, ikan kecil dan lain sebagainya. Mereka berpindah-pindah tempat bahkan tempat yang jauh dari desanya di kecamatan lain untuk mencari daerah persawahan yang baru selesai panen. Peternak akan melokasikan daerah tersebut sebagai daerah gembalaannya bahkan tinggal di tempat itu atau beberapa waktu untuk menjaga pada malam hari sebelum sawah ditanam padi kembali oleh pemilik sawah atau karena kondisi makanan itik alam di lokasi tersebut sudah berkurang.

Peternak itik di daerah ini melakukan kegiatannya berdasarkan pengalaman beternak mereka. Perkandangan yang sederhana dan sistem pemeliharaan ekstensif dengan menggembalakan ternak yaitu menjaga dan menggiring ternak untuk mencari makanan sendiri di persawahan, danau atau dirawa. Pemeliharaan secara gembala ini dilakukan oleh peternak itik sebagai pertimbangan ekonomi yaitu mengurangi biaya produksi khususnya biaya pakan. Karakteristik pemeliharaan sistim gembala dalam memanfaatkan sumber daya alam perlu dikaji yang memberikan nilai ekonomi bagi peternak. Informasi ini sangat bermanfaat sebagai sumber informasi ilmiah peternak, peneliti, dan pemerintah sebagai tujuan untuk membangun peternakan itik di kabupaten ini.

\section{Material dan Metode}

Lokasi penelitian didaerah Pesisir Danau Tondano, meliputi Kecamatan Tondano Timur, Tondano Barat, Romboken, Kakas dan Langowan Timur yang berdasarkan hasil survey terdapat populasi ternak dan populasi peternak itik petelur. Penelitian dilakukan dengan metode survey. Jenis data adalah data primer dan data sekunder. Data primer diambil melalui teknik wawancara dan kuesioner. Data sekunder diambil dari dinas/instasi yang terkait. Jumlah sampel dalam penelitian ini adalah 72 peternak itik yang diambil secara purposive sampling. Secara purposive sampling yaitu berdasarkan pertimbangan pada peternak itik yang memelihara itik gembala yang berpindahpindah lokasi gembala mengikuti masa panen padi dan memiliki ternak minimal 100-200 ekor.

Analisis data menggunakan analisis deskriptif dalam menggambarkan karakterisktik peternak itik gembala dalam hal jumlah pindah lokasi gembala, jarak daerah gembala dari tempat tinggal. Hasil dibuat dengan model tabulasi, persentase dan perhitungan nilai rupiah dalam biaya pakan (Rp). Untuk menghitung nilai manfaat ekonomi dari sistim gembala yang memanfaatkan sumber daya alam sebagai pakan alam dengan menggunakan teori Hari Orang Kerja (HOK) ataupun menggunakan perhitungan JKSP (Jam Kerja setara Pria), dimana kegiatan menjaga/menggiring ternak setiap harinya (Jam) dinilai sebagai nilai pakan alam yang dihitung dari upah(Rp/Hari) yang diberikan diwilayah setempat (Rp. 100.000/hari).

\section{Hasil dan Pembahasan \\ Pemeliharaan Sistim Gembala.}

Hasil pengamatan menunjukan bahwa terdapat dua sistem pemeliharaan yang dilakukan oleh peternak itik Petelur di kabupaten Minahasa yaitu sistem gembala dan sistem semi-intensif. Pemeliharaan itik sistem gembala yang umumnya digunakan oleh peternak di kabupaten Minahasa. Pada usaha itik petelur sistem gembala, peternak melepas ternak itik di daerah yang menyediakan pakan alam yaitu sisa butiran padi sisa, keong kecil, serangga dan lainnya. Lokasi ini yaitu di daerah persawahan habis panen dan rawa .

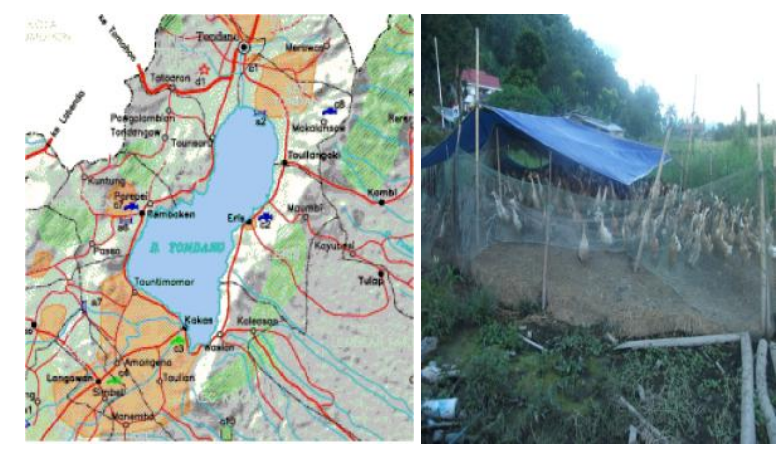

Gambar 1. Peta Perpindahan Daerah dan Kandang Sistem Pemeliharaan Gembala

Sistem gembala menurut hasil wawancara sudah menjadi tradisi yang diturunkan oleh orang tua peternak khususnya didaerah kecamatankecamatan yang berlokasi di pinggiran danau Tondano. Di Indonesia pemeliharaan itik dengan sistem gembala masih ada terutama pada daerahdaerah persawahan seperti laporan dari Suswoyo dan Ismoyowati (2010) yang meneliti pemeliharaan sistem gembala di kabupaten Purbalingga yang merupakan daerah pertanian (sawah) dan kabupaten Cilacap yang merupakan daerah perikanan, yang selanjutnya menyatakan bahwa sistem gembala di daerah Kabupaten Purbalingga 
dengan melepas ternak dari jam 7 pagi hingga jam 4 sore sedangkan peternak gembala di Kabupaten Cilacap dua kali frekwensi melepas yaitu jam 8 sampai jam 10 pagi dan jam 1 siang sampai jam 2 siang. Peternak itik di Minahasa dalam berusaha itik menggembalakan ternaknya dimulai dari pagi jam 6 dan dikumpul jam 5 sore dilokasi gembala dimana peternak biasanya ikut tinggal di daerah gembala yang bahkan bisa jauh dari rumahnya untuk menjaga ternak itik dari siang hingga malam hari.

Pada daerah gembala dibuat kandang sederhana berupa pagar yang mengitari kandang dibuat dari jaring atau bamboo, terpal sebagai atap dan pada lantai tanah dialasi dengan jerami padi agar tidak becek dan lembab. Tujuan pembuatan kandang oleh peternak adalah sebagai pelindung pada malam hari dari cuaca hujan dan pencurian ataupun gangguan hewan seperti anjing dan sebagai tempat bertelur itik. Kandang sederhana ini bersifat sementara dan mudah dibongkar karena sewaktu-waktu peternak pindah lokasi gembala.

Jarak Pindah Lokasi Gembala dari Tempat Tinggal dan Intensitas Pindah Lokasi

Tabel 1. Karakteristik Manajemen Usaha Itik Petelur Sistem Gembala Untuk Jarak Daerah Gembala dan Intensitas Pindah

$(\%)$

Jarak daerah gembala dari tempat tinggal

$$
\begin{aligned}
& \leq 2 \mathrm{~km} \\
& >2 \mathrm{~km}
\end{aligned}
$$

Intensitas pindah/ thn

$$
\begin{aligned}
& \leq 4 \text { /year } \\
& >4 \text { / year }
\end{aligned}
$$

Tabel 1 dapat menjelaskan tentang jarak pindah lokasi dari tempat tinggal peternak ke daerahdaerah gembala yaitu $77 \%$ melakukan perpindahan daerah gembala yang jauh dari tempat tinggalnya lebih dari $2 \mathrm{~km}$, sedangkan sisanya 33\% hanya melakukan perpindahan didaerah dekat tempat tinggalnya tidak lebih dari $2 \mathrm{~km}$. Beberapa alasan yang menyebabkan peternak melakukan perpindahan yang jauh dari tempat tinggalnya (bahkan bisa perpuluh kilometer jaraknya) yaitu : lahan gembala di daerahnya yang terbatas karena telah ditanami padi, jumlah peternak yang menggembala di daerah tersebut cukup banyak, pemilikan ternak itik yang banyak dan banyaknya daerah di tempat lain yang sementara memanen padi. Hal ini sejalan dengan penelitian dari Setioko (1984) peternak itik gembala di pulau Jawa melakukan perpindahan itiknya dengan menggunakan kendaraan mengangkut ternaknya ke daerah lain khususnya daerah pertanian padi yang baru selesai panen padi yang jaraknya hingga puluhan kilometer dari tempat tinggal peternak hal ini disebabkan karena terbatasnya lahan gembala di daerah tempat tinggalnya.

Intensitas pindah ke daerah gembala menunjukan bahwa kelompok kurang dari 4 kali setahun terbesar yaitu $64 \%$ dan kelompok lebih dari 4 kali pindah lokasi gembala adalah 36\%. Kelompok pertama melakukan perpindahan kurang dari 4 kali karena merasa cukup luasnya daerah gembala didaerah mereka tinggal sehingga mereka tidak banyak melakukan perpindahan. Perpindahan daerah gembala ini ditunjang dengan pola tanam padi di kabupaten Minahasa yang tidak serentak sehingga saat selesai panen padi memberi peluang peternak berpindah lokasi mengembala. Perpindahan ternak itik terkosentrasi didaerah persawahan dan rawa daerah pinggiran Danau Tondano. Menurut BPS Sulut (2018) luas daerah persawahan padi di kabupaten Minahasa yaitu 13.002 Ha yang umumnya terletak di pinggiran danau Tondano.

Manfaat Penggunaan Sistem Gembala Bagi Peternak Itik Petelur Di Kabupaten Minahasa

Di Kabupaten Minahasa khususnya didaerah pinggiran danau Tondano, hal yang membuat peternak itik menggunakan sistim gembala yaitu karena Pola tanam padi didaerah persawahan yang tidak serentak. Keadaan ini memberi keuntungan bagi peternak itik untuk melepas ternaknya dengan berpindah pindah lokasi karena sebagian lahan habis lepas panen tidak merata. Tujuan peternak itik menggembalakan ternaknya di daerah persawahan habis panen agar supaya ternak dapat makan sisa sisa pangan padi yang terbuang atau pun bulir padi yang masih muda yang tidak digunakan selain itu alam menyediakan serangga, keong, ikan kecil dan berbagai jenis tanaman air yang dapat dikonsumsi ternak itik. Pakan alam yang tersedia bermanfaat bagi ternak karena mengandung kebutuhan nutrisi yang pada akhirnya ternak dapat memproduksi telur dan daging.

Hasil penelitian dari Pangemanan (2018), menyatakan bahwa ternak itik gembala diberi pakan tambahan berupa keong (renga) kecil dan jagung agar supaya produksi telur stabil. Pakan keong dibeli peternak pada pengumpul keong (renga) di danau Tondano. Pada saat pengambilan data didapat bahwa kegiatan menambah pakan keong sudah tidak lagi dilakukan karena pakan keong sudah tercemar dengan belerang karena aktivitas alam dari Danau Tondano. Pakan keong yang tercemar belerang dapat menyebabkan itik tidak berproduksi telur.

Hasil penelitian pada Gambar 1 menunjukan jenis-jenis kegiatan dalam usaha itik gembala di kabupaten Mlnahasa yaitu kegiatan menjaga, kegiatan memberi pakan, membeli pakan, kumpul telur dan pindah lokasi. Penggunaan tenaga kerja menjaga/menggiring /menggembala ternak itik adalah kegiatan yang persentase waktunya paling besar yaitu $66 \%$ atau dalam penggunaan waktu 816.78 JKSP/tahun atau 2,24 JKSP/hari. Kegiatan ini persentasenya tinggi karena kegiatan ini memerlukan waktu untuk memperhatikan /mengawas itik dalam mencari makan yang bergerak tanpa arah. 


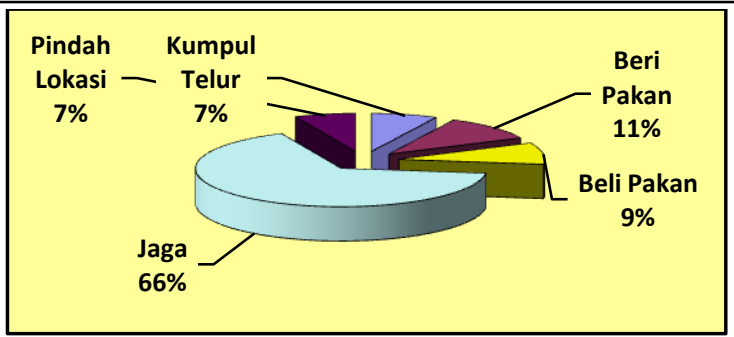

Gambar 1. Distribusi Menurut Jenis Pekerjaan Usaha Itik Sistim Gembala

Pola tanam padi didaerah Kabupaten Minahasa tidak serentak dimana pada beberapa areal sawah yang masih ditanami padi dan sebagian lahan lain sementara panen atau tidak ditanami sehingga peternak harus menjaga ternaknya untuk tidak masuk ke daerah tanam tersebut. Selain itu peternak itik juga harus mengontrol kondisi ternaknya apakah sudah mendapat makanan alam yang cukup sehingga peternak akan menggiring ke tempat yang masih banyak pakan alamnya.

Kegiatan usaha itik lainnya dilakukan saat itik dalam keadaan dibiarkan menggembala tanpa pengawasan karena aman atau karena ada anggota keluarga lain yang menjaga, maka petani akan melakukan kegiatan mengumpul telur, membeli pakan, menjual telur dan lainnya. Kegiatan memberi pakan dilakukan saat itik kurang mendapat makanan di alam yang dapat berpengaruh terhadap produksi telur. Kegiatan tersebut dilakukan pada siang hari di lahan gembala atau sore hari pada saat ternak hendak dikandangkan. Pindah lokasi gembala dilakukan peternak saat daerah gembala telah berkurang pakan alamnya atau karena lokasi akan ditanami padi maka peternak akan mencari lokasi gembala baru khususnya didaerah yang baru selesai panen padi.

Rilianti (2001) menjelaskan bahwa rata-rata curahan tenaga kerja keluarga pada usaha itik petelur sistim intensif adalah 34,14 JKSP/bulan atau 409,68 JKSP/tahun. Bila membandingkan dengan sistim pemeliharaan intensif maka pemeliharaan sistim gembala lebih memerlukan curahan waktu kerja yang lebih banyak karena peternak harus memperhatikan ternaknya dari banyak faktor seperti keamanan, pakan dan produksi ternak, sedangkan untuk sistim intensif lebih kurang curahan waktu kerja karena ternak dikandangkan sehingga tidak memerlukan waktu untuk menjaga, menggiring dan mengontrol.

Manfaat ekonomi waktu gembala yang dihitung sebagai biaya pakan alam didapat dengan perhitungan sebagai berikut : diaman 2,24 jam dibagi dengan 8 jam kerja (lama penuh waktu kerja) dikalikan dengan upah harian yang diberikan untuk menjaga itik dalam sehari (Rp. 100.000).- Maka Didapat hasil Rp 28.000.- per hari Atau dalam 1 tahun dengan nilai Rp. 10.220.000.-. . Biaya pakan alam sebesar Rp. 28.000 untuk peternak kecil/tradisional mempunyai nilai yang berarti dalam mengurangi biaya produksi usaha itik tradisional di

\section{kabupaten}

$\mathrm{dkk}, 2018)$

\section{Kesimpulan}

Manfaat ekonomi dihitung sebagai biaya pakan dengan nilai Rp. 10.220.000 per tahun atau Rp. 28.000 per hari (utk peternak dgn jumlah ternak 100200 ekor

\section{Daftar Pustaka}

Biro Pusat Statistik . 2018. Minahasa dalam Angka. BPS. Minahasa.

Pangemanan, S.P., Wantasen, E., SAjouw, A., Oroh, F. N S dan Rawis, J.O. 2017.Kebijakan Pemerintah Untuk Meningkatkan Peternak Itik Petelur Sistim Gembala di Kabupaten Minahasa.. Prosiding Seminar Nasional Pengembangan Unggas Lokal di Indonesia. Manado 30 Agustus 2017. Fakultas Peternakan Universitas Sam Ratulangi

Pangemanan, S. P., Pandey J dan Rawis , J.O. 2018. Faktor-faktor yang Mempengaruhi Biaya Produksi Usaha Itik Tradisional di Kabupaten Minahasa. Prosiding Seminar Nasional Persepsi III. Manado 6 September 2018. Perkumpulan IImuwan Sosial Ekonomi Peternakan Indonesia. Manado HIm 270-378

Setioko A. R. 1984. Sistim Pemeliharaan Itik Gembala di Pedesaan. Wartazoa Vol. 1. July.

Suswoyo, I dan Iswoyowati. 2010. Performans Produksi Telur Itik Lokal Yang Dipelihara Secara Terkurung, Prosiding. Seminar Nasional Unggas Lokal ke-IV. Fakultas Peternakan Universitas Diponegoro, Semarang. 